\title{
PEMBELAJARAN KOOPERATIF TIPE THINK PAIR SHARE (TPS) MENGGUNAKAN ALAT PERAGA UNTUK MENINGKATKAN MOTIVASI DAN HASIL BELAJAR SISWA KELAS V SDN PAKAUMAN 1 BANJARMASIN
}

\author{
Normalasarie, Muhammad Rizki Zulkarnain \\ STKIP PGRI Banjarmasin, STKIP PGRI Banjarmasin \\ normala.sari142@gmail.com, rizkizulkarnain@stkipbjm.ac.id
}

\begin{abstract}
Abstrak: Berdasarkan hasil observasi awal pembelajaran di SDN Pakauman 1 Banjarmasin umumnya masih menggunakan pembelajaran yang masih berpusat pada guru. Pada pembelajaran ini biasanya guru menggunakan metode ceramah,tanya jawab,dan tugas latihan atau soal. Kesalahan konsep yang dialami siswa menyebabkan sekitar 50\% hasil belajar dan motivasi siswa masih di bawah ketuntasan minimal. Untuk mengatasi masalah tersebut perlu dilakukan penelitian tentang penerapan model pembelajaran yang dapat menanamkan pemahaman siswa. Tujuan Penelitian ini adalah untuk mengetahui rancangan pembelajaran jaring-jaring balok melalui strategi (TPS) Think Pair Share sebagai upaya membangun kemampuan belajar matematika. Subjek penelitian ini adalah siswa kelas V SDN Pakauman 1 Banjarmasin. Jenis penelitian yang digunakan adalah penelitian Tindakan Kelas (PTK). Pelaksanaan penelitian ini terdiri dua siklus. Data yang dikumpulkan meliputi : (1) data utama, yaitu proses pembelajaran yang dilakukan (2) data pendukung yang terdiri dari : (a) hasil tes siswa (b) lembar observasi belajar siswa (c) hasil tes siswa (d) hasil observasi aktivitas guru dan siswa. Hasil penerapan pembelajaran.Think Pair share dapat meningkatkan hasil belajar dan motivasi siswa. Pada siklus pertama diperoleh data dengan kriteria baik, namun ada beberapa siswa yang masih belum memahami konsep. Hasil belajar siswa secara klasikal tuntas sebanyak $60 \%$ sehingga tindakan ini belum mencapai keberhasilan. Setelah perbaikan pembelajaran dilakukan siklus kedua mencapai $80 \%$ dengan rata-rata nilai keseluruhan sebesar 86,31\%. Berdasarkan hasil penelitian ini penerapan Think Pair Share dapat meningkatkan motivasi dan hasil belajar siswa SDN Pakauman 1 Banjarmasin.
\end{abstract}

Kata Kunci: Strategi TPS Think Pair Share, membangun kemampuan belajar matematika, pembelajaran jaring-jaring balok

Sekolah Dasar merupakan lembaga pendidikan formal pertama yang akan memberi bekal pengetahuan dan sikap serta keterampilan kepada siswa agar sanggup menghadapi perubahan keadaan dalam kehidupan dan mengikuti pendidikan yang lebih tinggi pada jenjang selanjutnya. Pada jenjang ini siswa akan mempelajari berbagai matapelajaran,diantaranya adalah matematika. Pada sekolah dasar matematika merupakan salah satu ilmu dasar yang diajarkan guna menumbuhkembangkan kemampuan berpikir logis.

Pendidikan metematika memiliki objek yang abstrak serta berpola pikir deduktif dan konsisten. Pada jenjang pendidikan dasar diharapkan dapat menata nalar, pembentukan sikap serta keterampilan dalam menerapkan matematika dalam kehidupan sehari-hari atau dalam mempelajari berbagai ilmu pengetahuan.Menurut Soedjadi (2000) tujuan pembelajaran matematika di sekolah adalah agar siswa sanggup 
menghadapi perubahan keadaan di dalam kehidupan dan di dunia yang selalu berkembang, melalui latihan bertindak atas dasar pemikiran secara logis, rasional, kritis, cermat, jujur, efektif, dan efesien, serta mempersiapkan agar siswa dapat menggunakan matematika dalam kehidupan sehari-hari dan mempelajari berbagai ilmu pengetahuan.

Geometri merupakan salah satu cabang matematika yang penting untuk dikaji, hal ini dikarenakan geometri banyak digunakan dalam kehidupan sehari-hari. Geometri telah dipelajari oleh siswa sekolah dasar. Berdasarkan kurikulum 2013, siswa kelas $\mathrm{V}$ akan mempelajari tentang jaringjaring bangun ruang sederhana. Untuk memotivasi dan meningkatkan pemahaman siswa perlu dilakukan beberapa upaya.Upaya tersebut dapat berupa manipulasi benda konkrit berupa alat peraga untuk mengkonstruk pemahaman mereka.Pendapat Usman dan Asnawir (2002) media pembelajaran menurut National Education Association (NEA) adalah benda yang dapat dimanipulasikan, dilihat, didengar, dibaca, atau dibicarakan beserta instrumen yang dipergunakan dengan baik dalam kegiatan belajar mengajar, serta dapat mempengaruhi efektifitas program instruksional. Bruner Sujana, ( 1990) bahwa dalam proses belajar anak sebaiknya diberi kesempatan memanipulasi benda-benda (alat peraga), anak akan langsung melihat bagaimana keteraturan dan pola struktur yang terdapat dalam benda yang sedang diperhatikannya.

Penggunaan alat peraga dalam pembelajaran yang dapat memberikan rangsangan sehingga akan meningkatkan motivasi siswa. Dalam teori behaviorisme menjelaskan motivasi sebagai fungsi rangsangan (stimulus) dan respons. Dari teori kognitif, motivasi merupakan fungsi dinamika psikologis yang lebih rumit karena melibatkan kerangka berfikir siswa terhadap prilaku Sofa,( 2008).Motivasi mempengaruhi semua aspek pendidikan, yang berkontribusi pada keberhasilan siswa di sekolah.Siswa yang memiliki motivasi belajar akan menggunakan proses pengetahuan dalam memahami dan mempelajari suatu materi dengan baik, sehingga hasil proses itu akan terserap dan tersimpan dalam diri siswa dalam waktu lama.

Slameto(2010)mengemukakan faktorfaktor yang mempengaruhi motivasi belajar siswa ada dua yaitu faktor intern dan faktor ekstern. Yang termasuk dalam faktor intern diantaranya adalah faktor jasmaniah (kesehatan, cacat tubuh), faktor psikologis (inteligensi, perhatian, minat, bakat, motif, kematangan dan kesiapan),dan faktor kelelahan. Sedangkan faktor ekstern adalah faktor keluarga (cara orang tua mendidik, relasi antar anggota keluarga, suasana rumah, keadaan ekonomi keluarga, pengertian orang tua, latar belakang kebudayaan), faktor sekolah (metode mengajar, kurikulum, relasi guru dengan siswa, relasi siswa dengan siswa, disiplin sekolah, alat pelajaran, waktu sekolah, standar pelajaran diatas ukuran, keadaan gedung, metode belajar, dan tugas rumah), faktor masyarakat(kegiatan siswa dalam masyarakat, mass media, teman bergaul, bentuk kehidupan masyarakat).

Mengingat metode pembelajaran merupakan salah satu faktor yang menentukan motivasi belajar siswa (Slameto (2010) Dimyati dan Mudjiono(2009), ada berbagai macam model pembelajaran yang dipertimbangkan untuk diterapkan pada pembelajaran matematika sehingga motivasi 
belajar siswa meningkat. Salah satunya adalah model cooperativelearning.

$$
\text { Slavin (2005) menyatakan }
$$

pembelajaran kooperatif atau sering disebut dengan cooperative learning adalah suatu pembelajaran dimana siswa belajar dan bekerja dalam kelompok- kelompok kecil secara kolaboratif yang anggotanya 4-6 orang dengan struktur kelompok heterogen. Menurut Lie dalam Isjoni (2011) menyebut cooperative learning dengan istilah gotong royong, yaitu sistem pembelajaran yang memberi kesempatan kepada peserta didik untuk bekerjasama dengan siswa lain dalam tugas terstruktur, dan hanya berjalan jika sudah tebentuk kelompok atau suatu tim yang didalamnya siswa bekerjasama secara terarah untuk mencapai tujuan yang ditentukan dengan jumlah anggota kelompok yang terdiri dari 4-6 orang saja. Dari pendapat tersebut dapat disimpulkan bahwa pembelajaran koperatif tidak hanya sekedar belajar kelompok atau kerja kelompok, tetapi lebih dituntut untuk bekerjasama secara terstruktur dan efektif sehingga menghasilkan pembelajaran yang interaktif antar siswa.

Pembelajaran kooperatif mempunyai beberapa tipe yaitu Jigsaw, Think Pairs Share (TPS), Numbered Heads Together (NHT), Group Investigation, Make a Match, Listening Team, Inside-Outside Circle, Bambo Dancing, Point-Counter-Point, The Power of Two dan Listening Team (Suprijono,2012). Sehingga guru mempunyai tugas untuk memilih salah satu tipe pembelajaran kooperatif agar sesuai dengan harapan yang diinginkan yaitu model pembelajaran Think Pair Share (TPS).

Model pembelajaran kooperatif tipe Think Pair Share (TPS) dikembangkan pertama kali oleh Frank Lyman dari University of Maryland. Pembelajaran kooperatif tipe Think Pair Share (TPS) memiliki prosedur yang memberikan siswa lebih banyak waktu untuk berpikir, menjawab dan saling membantu satu sama lain. Selain itu, tipe Think Pair Share (TPS) ini relatif sederhana, tidak menyita waktu dalam mengatur tempat duduk dimana siswa dikelompokkan secara berpasangan sehingga dapat mengaktifkan proses diskusi dalam pembelajaran kooperatif, serta bisa dikolaborasikan dengan menambahkan media pembelajaran agar pengalaman belajar yang didapat secara langsung bisa menanamkan konsep yang ingin disampaikan oleh guru. Pada tipe ini guru memberikan persoalan kepada siswa dan siswa bekerja kelompok dengan cara berpasangan (thinkpairs), kemudian presentasi kelompok (share) Slavin (2005). Dengan cara berpasangan diharapkan siswa mampu termotivasi dalam belajar, mengurangi rasa jenuh dan bosan sehingga akan mempengaruhi hasil belajar siswa.

Berdasarkan latar belakang di atas peneliti menganggap penelitian tentang pembelajaran kooperatif tipe Think Pair Share (TPS) menggunakan alat peragadi kelas penting dilakukan. Karena dapat meningkatkan motivasi siswa yang pada akhirnya dapat meningkatkan hasil belajar siswa itu sendiri. Oleh karena itu perlu dilakukan penelitian "Pembelajaran Kooperatif Tipe Think Pair Share (TPS) Menggunakan Alat Peraga Untuk Meningkatkan Motivasi dan Hasil Belajar Siswa Kelas V SDN Pakauman 1 Banjarmasin"

\section{Metode Penelitian}

Penelitian ini menggunakan pendekatan kualitatif, karena (1) peneliti akan 
memaparkan hasil observasi dan pekerjaan siswa untuk mengetahui apa yang terjadi dalam proses pembelajaran dengan menggunakan pembelajaran kooperatif tipe TPS dan (2) memperoleh gambaran tentang motivasi dan aktivitas dari subjek penelitian yang muncul selama proses pembelajaran berlangsung. Penelitian dengan pendekatan kualitatif yaitu penelitian yang datanya dinyatakan dalam bentuk verbal dan dianalisis dengan statistik non parametrik.

Penelitian ini merupakan penelitian tindakan kelas (PTK). Menurut Akbar (2009) penelitian tindakan kelas adalah proses investigasi terkendali untuk menemukan dan memecahkan masalah pembelajaran dikelas. Proses pemecahan masalah tersebut dilakukan secara bersiklus. Latief (2010) menyatakan bahwa penelitian tindakan kelas adalah suatu penelitian yang dirancang khusus untuk meningkatkan kualitas praktek di kelas.

Dalam penelitian ini peneliti bertindak sebagai instrumen utama. Peneliti merupakan pelaksana tindakan dan sekaligus mengumpulkan data. Peneliti terlibat dalam pengalaman yang berkelanjutan dan terus menerus dengan para partisipan Creswell (2012). Moleong (2011) peneliti sendiri atau dengan bantuan orang lain merupakan alat pengumpul data utama.

Penelitian ini dilaksanakan di SDN Pakauman 1 Banjarmasin. Pelaksanaan penelitian pada tahun ajaran 2016 / 2017.

Peneliti menggunakan beberapa cara sebagai acuan pengumpulan data, yaitu:

(1) data utama, yaitu proses pembelajaran yang dilakukan (2) data pendukung yang terdiri dari : (a) hasil tes siswa (b) lembar observasi belajar siswa (c) hasil tes siswa (d) hasil observasi aktivitas guru dan siswa

Lembar validasi dalam penelitian ini terdiri dari: (1) lembar validasi RPP
2. Data hasil pengamatan aktivitas guru dan siswa

Pengamatan dilakukan selama proses pembelajaran berlangsung. Data hasil pengamatan aktivitas guru dan siswa di dapat dari lembar pengamatan (observasi) yang telah diisi oleh pengamat. Lembar pengamatan aktivitas siswa disusun berdasarkan aspekaspek motivasi yang diukur berpedoman pada hasil (ARCS) Model Keller dan Krapp (1987) Model ARCS didasarkan pada perpaduan konsep motivasi dan karakteristik ke dalam empat kategori yaitu attention (A) relevance (R), convidance (C) satisfaction (S) keempat kategori mewakili kondisi yang diperlukan bagi seseorang agar termotivasi.

3. Data hasil Tes

Data hasil tes di peroleh dari tes tertulis. Tes yang dilaksanakan pada setiap akhir tindakan. Pada siklus pertama 11 dari 20 siswa $55 \%$ dengan nilai rata-rata $69,5 \%$ dan pada siklus kedua 18 orang dari 20 siswa tuntas dengan nilai rata-rata 79,6\%

\section{Hasil Penelitian dan Pembahasan}

\section{Hasil}

Hasil Pengamatan terhadap motivasi terlihat menarik dibuktikan berdasarkan data yang diperoleh pada pertemuan pertama sampai empat disiklus 1 ada 15 siswa yang memberi pendapat dan ada 10 siswa yang menjawab dan berkelompok. Data hasil belajar siswa di siklus1 yaitu 55\% dengan nilai rata-rata $69,65 \%$. Sedangkan pada siklus II pada pertemuan pertama sampai empat motivasi belajar siswa cukup baik, ada 18orang siswa yang bekerja sama dan 15 orang siswa yang dinyatakan bertanya. Hal ini diimbangi dengan hasil belajar siswa yang juga meningkat dari 20 orang siswa ada 18 orang siswa yang Tuntas dengan nilai 
persentase $95 \%$, nilai rata-rata hasil belajar siswa adalah 79,6\%. Berdasarkan hasil analisis data di atas, dapat disimpulkan bahwa pembelajaran pada siklus II telah mencapai kriteria keberhasilan baik segi proses maupun dari segi hasil. Dengan demikian dapat diputuskan bahwa siklus II tidak perlu diulang

Pada perencanaan tindakan,peneliti mempersiapkan perangkat pembelajaran dan instrumen penelitian, yaitu: (1) membuat Rencana Pelaksanaan Pembelajaran (RPP) untuk 2 (dua) siklus,yang siklus pertama 4 kali pertemuan dan siklus kedua 4 kali pertemuan, dan diakhir pada tiap siklus dilakukan tes belajar dan dilakukan pengamatan motivasi. (2) membuat Lembar Kerja Siswa (LKS) dengan penemuan terbimbing, (3) membuat tes siklus, lembar observasi, dan lembar pedoman wawancara.

Pada tahap pelaksanaan, peneliti bertindak sebagai guru yang melaksanakan kegiatan pembelajaran dan diamati oleh dua observer. Proses pembelajaran dilaksanakan sebanyak 4x pertemuan yang setiap akhir pertemuan dilaksanakan tes formatif untuk melihat keterlaksanaan pembelajaran. Kemudian, tahap pelaksanaan kegiatan ini diakhiri dengan $1 \mathrm{x}$ tes akhir untuk melihat keberhasilan pelaksanaan selama pembelajaran berlangsung.

\section{Pembelajaran Siklus I}

Siklus I dilaksanakan 4 kali pertemuan yaitu tanggal 27 April, 2 Mei, 4 Mei, dan 9 Mei 2017. Pada pertemuan pertama, kedua, dan ketiga, siswa diberikan materi dengan menerapkan model pembelajaran kooperatif tipe TPS. Tujuan pembelajaran pada pertemuan pertama yaitu siswa dapat memahami sifat-sifat bangun datar. Di awal pertemuan peneliti memberikan salam, kemudian memeriksa kehadiran siswa sehingga mengkondisikan siswa agar benar- benar siap untuk mengikuti pelajaran. Semua siswa hadir pada pertemuan itu.

Materi yang disajikan pada pertemuan pertama adalah mengenal sifat bangun ruang sederhana. Pertemuan kedua tentang mengenal jaring-jaring berbagai bangun ruang sederhana. Pertemuan ketiga tentang mengenal sifat kesebangunan berbagai bangun datar sederhana. Untuk pertemuan keempat diadakan evaluasi belajar siklus I.

Pertemuan yang menggunakan pembelajaran Think Pair Share ini disesuaikan dengan RPP yang telah dibuat dan divalidasi oleh validator. Pembelajaran ini dibagi tiga tahap pembelajaran, yakni pendahuluan, kegiatan inti dan penutup. Pada tahap pendahuluan peneliti menyampaikan informasi tentang tujuan pembelajaran kepada siswa. Setelah penyampaian tujuan, kemudian guru memberikan apersepsi dan motivasi berupa pengecekan pengetahuan prasyarat kepada siswa, melalui tanya jawab materi berkaitan dengan unsur-unsur bangun ruang. Guru memberi pertanyaan kepada siswa untuk menyebutkan bentuk-bentuk bangun ruang dalam kehidupan sehari-hari yang mereka temui. Guru memisalkan ruang kelas berupa kubus, siswa diminta menunjukkan titik dan rusuk. Guru mengarahkan siswa dengan pertanyaan yang dapat membangun pengetahuan siswa untuk dapat memahami rusuk yang sejajar.

Setelah penyampaian apersepsi dan motivasi, guru menjelaskan langkah-langkah pembelajaran yang digunakan pada pembelajaran yaitu siswa akan berpikir secara individu dengan menjawab LKS, di dalam LKS tersebut ada petunjuk. Selanjutnya tahap pair, siswa berpasangan dan mengerjakan LKS.

\section{Tahap Think}


Guru memberikan LKS kepada siswa untuk dikerjakan secara individu, siswa mengamati lembar LKS yang ada pada meja mereka masing-masing untuk mengerjakan LKS. Guru memberikan waktu untuk mengerjakan LKS selama 15 menit, siswa mengerjakan LKS secara individu. Guru berjalan berkeliling menghampiri siswa yang kesulitan dan menanyakan jawaban siswa untuk mengetahui kemampuan yang mereka miliki. Siswa mengerjakan LKS dengan lancar, guru mempersilahkan siswa bertanya jika ada kesulitan dalam menjawab LKS.

Hasil kerja siswa menunjukkan bahwa bangun bola dianggap sebagai bangun datar yang berbentuk lingkaran. Untuk mengatasi hal tersebut, guru memberikan pertanyaanbantuan kepada siswa yaitu dengan membedakan bangun ruang dengan bangun datar. selama proses tindakan pertama berlangsung masih ada terlihat pada tahap think terdapat siswa tidak berpikir secara individu dalam menyelesaikan LKS. Ada siswa masih tampak mencontek dan bekerjasama dengan siswa lainnya.

Materi selanjutnya yang ada pada LKS 1 tahap Pair. Siswa telah memiliki konsep dasar sebelum mempelajari materi bangun datar, Setelah itu peneliti akan membagi kelompok untuk tahap Pair.

\section{Tahap Pair (berpasangan)}

Kegiatan pada tahap ini yaitu guru meminta siswa untuk berpasangan dengan kelompoknya. Pembentukan kelompok berdasarkan pada hasil tes awal siswa dan hasil konsultasi dengan guru matematika. Masingmasing siswa menggeser meja dan kursinya agar dapat duduk bersama pasangannya. Selanjutnya, peneliti membagikan LKS 1 tahap Pair. Setiap kelompok diminta untuk mendiskusika penyelesaian tiga permasalahan yang ada di LKS. Susunan kelompok yang hanya terdiri dari dua anggota sangat memudahkan siswa dalam berdiskusi.Selama siswa berdiskusi, peneliti berkeliling mengamati hasil pekerjaan siswa.

Peneliti juga memberikan kesempatan kepada setiap kelompok untuk bertanya jika menemui kesulitan dalam mengerjakan soal tersebut.

\section{Tahap Share}

Pada tahap ini guru menunjuk kelompok secara bergantian untuk mempresentasikan hasil kerja kelompok mereka. Tidak semua kelompok maju mengingat waktu yang diperlukan pada pertemuan ini sangat singkat, hanya yang mewakili permasalahan pada LKS yang sesuai dengan tujuan yang diharapkan. Kelompok 1 mempresentasikan hasil kerja mereka, siswa dipersilahkan untuk mengajukan pendapat jika terjadi perbedaan jawaban. Guru menegaskan kepada siswa untuk memperhatikan penjelasan kelompok yang presentasi dan melarang melakukan aktifitas yang lain.Kelompok 2 menyanggah pendapat dari kelompok 1 , ternyata pendapat yang mereka maksudkan sama saja hanya berbeda pengucapannya saja.Mengetahui hal tersebut guru menampilkan bangun bola pada papan tulis kemudian memberikan pertanyaan-pertanyaan arahan kepada siswa. Melalui pertanyaan arahan yang diberikan guru, siswa akhirnya dapat menyimpulkan bahwa bola tidak memiliki tinggi namun memiliki diameter.Diskusi pada tahap share berlangsung dengan lancar siswa aktif memberikan pendapat mereka. Siswa membuat kesimpulan dari hasil kerja mereka berkaitan materi yang ada pada LKS. Pada tahap penutup, guru bersama siswa membuat kesimpulan berkaitan permasalahan yang telah diselesaikan pada tahap think, tahap pair, maupun pada tahap share. Setelah membuat kesimpulan guru juga memberikan penguatan 
terhadap kesimpulan dari materi yang telah dipelajari. Sebelum mengakhiri tahap penutup, guru memberikan tes berkaitan materi yang telah dipelajari. Tes digunakan agar guru dapat mengetahui kemampuan siswa dan keterlaksanaan pembelajaran.

Siswa belum mampu mengaitkan dan mengidentifikasi konsep titik sudut,rusuk dan sisi bangun ruang bahkan masih belum benar dalam penulisan notasi titik sudut dan rusuk. Berdasarkan hasil jawaban siswa, peneliti mengamati bahwa siswa belum memahami permasalahan dalam soal dan menyampaikan ide-ide matematisnya secara tertulis.

\section{Kegiatan Penutup}

Pada tahap penutup, peneliti bersama siswa membuat kesimpulan tentang materi yang telah dipelajari hari ini yaitu tentang menyelesaiakan permasalahan yang berkaitan dengan bangun ruang. Setelah itu, peneliti memberikan informasi bahwa pada pertemuan berikutnya akan diadakan pembelajaran menggunakan alat peraga dan tes tertulis dengan materi Bangun ruang. Pada akhir pertemuan peneliti menutup pembelajaran dengan mengucapkan salam yang kemudian dijawab serempak oleh siswa.

Siklus I terdiri dari 4 tahapan tindakan dan tahapan-tahapannya adalah sebagai berikut:

(1) Rencana Tindakan

Rencana tindakan yang dilakukan pada siklus I yaitu:

(a) membagi siswa menjadi 17 pasang siswa sesuai nilai hasil ulangan harian materi sebelumnya.

(b) menyiapkan perangkat pembelajaran seperti rencana pelaksanaan pembelajaran (RPP) dan lembar kerja siswa (LKS), (c) menyiapkan instrumen penelitian yaitu lembar observasi aktivitas siswa dan soal evaluasi siklus I.

(2) Pelaksanaan Tindakan

Kegiatan pada tahap ini merupakan kegiatan pembelajaran dengan prosedur sebagai berikut:

(a) guru menyampaikan tujuan pembelajaran,

(b) guru memberikan apersepsi dan motivasi untuk menggali pengetahuan dan rasa ingin tahu siswa serta menginformasikan prosedur pembelajaran dengan menggunakan model pembelajaran kooperatif tipe TPS,

(c) guru membagikan LKS kemudian bersama-sama dengan siswa membahas materi yang ada di LKS,

(d) setelah pembahasan, siswa diminta untuk

memikirkan permasalahan (think) yang

diajukan di LKS secara mandiri,

(e) siswa yang telah selesai memikirkan permasalahan diminta berpasangan pair) dengan siswa lain yang sudah ditunjuk untuk menjadi pasangannya dan kemudian mendiskusikan apa yang telah mereka pikirkan sebelumnya,

(f) selama siswa berdiskusi, guru berkeliling memantau kegiatan siswa dan membimbing pasangan siswa apabila ada yang mengalami kesulitan,

(g) beberapa pasangan siswa diminta untuk mempresentasikan (share) hasil diskusi mereka di depan kelas dan pasangan siswa lain menanggapinya dengan bimbingan guru,

(h) selama pelajaran berlangsung, pengamat mengamati jalannya proses pembelajaran dan mengisi lembar observasi,

(i) guru memberikan penghargaan (berupa hadiah) bagi siswa yang memperoleh 
nilai tertinggi pada evaluasi di akhir siklus dan juga kepada kelompok predikat tertinggi untuk memotivasi siswa lain berprestasi.

(3) Observasi dan Evaluasi

Selama proses belajar mengajar di kelas berlangsung diadakan observasi dan penilaian terhadap motivasi belajar siswa di kelas. Observasi terhadap motivasi belajar siswa dilakukan oleh dua orang pengamat dengan mengisi lembar observasi motivasi belajar siswa pada saat proses pembelajaran dengan menggunakan model pembelajaran kooperatif tipe TPS berlangsung.

Hasil observasi pada pertemuan pertama, tidak semua siswa termotivasi dalam diskusi, baik dalam kelompok maupun antarkelompok (diskusi kelas). Siswa juga kurang memperhatikan penjelasan dari guru dan teman yang sedang mengerjakan soal di papan tulis. Masih ada anggota dalam pasangan siswa yang tidak mau untuk mengerjakan tugas yang telah diajukan. Hanya siswa yang tergolong pandai saja yang termotivasi mengerjakan tugas. Banyak pasangan siswa yang tidak membuat atau mencatat kesimpulan hasil diskusi.

Berdasarkan pengamatan, pembelajaran di kelas pada pertemuan pertama mengalami beberapa kendala. Guru terlihat kesulitan dalam mengatur kerja kelompok karena siswa masih belum terbiasa dengan model pembelajaran kooperatif tipe TPS ini. Suasana belajar di kelaspun menjadi ribut. Diharapkan pada pertemuan berikutnya guru harus lebih sering berkeliling untuk mengontrol siswa dalan pasangannya. Pengelolaan waktu saat pembelajaran berlangsung agar lebih ditingkatkan. Pada pertemuan pertama, pasangan siswa yang berkesempatan mempresentasikan pekerjaan mereka hanya berjalan satu pasangan saja itupun harus ditunjuk dan disuruh oleh gurunya

Hasil observasi pada pertemuan kedua, motivasi belajar siswa sudah dapat dirasakan meningkat. Masing-masing siswa di setiap kelompoknya sudah mulai terangsang untuk memecahkan permasalahan, walaupun di kelompok-kelompok bagian belakang masih terlihat siswa yang berbicara sendiri dan tidak memperhatikan penjelasan guru. Pasangan siswa yang mempresentasikan hasil diskusinya mulai banyak dan mulai berani maju ke depan tanpa disuruh oleh gurunya lagi, walaupun hanya kelompok-kelompok di depan saja. Diharapkan pada pertemuan selanjutnya, guru lebih membimbing kelompok-kelompok siswa yang duduk di belakang karena kelompok yang duduk di depan sudah mulai bagus dalam berdiskusi dengan pasangannya sendiri

Hasil observasi pada pertemuan ketiga, motivasi belajar siswa sudah dirasakan lebih meningkat. Sebagian siswa sudah mulai aktif dalam diskusi kelompok, walaupun belum aktif dalam diskusi kelas. Sebagian besar siswa sudah mulai mendengarkan dan memperhatikan penjelasan gurunya dengan saksama. Pasangan siswa yang duduk di belakang sudah mulai bisa berdiskusi serius dengan pasangannya.

Berdasarkan hasil pengamatan, pembelajaran di kelas pada pertemuan ketiga sudah berjalan dengan lancar. Waktu yang disediakan secara perlahan-lahan mulai dapat disesuaikan dengan rencana pembelajaran. Gurupun mulai sering mengontrol motivasi belajar siswa dalam pasangan. Tetapi dampaknya, beberapa pasangan siswa sering bertanya dan dalam memecahkan persoalan cenderung menunggu arahan dan bimbingan dari gurunya.

Dari hasil evaluasi siswa pada siklus I, diperoleh data sebanyak 11 dari 20 siswa 
tuntas dalam belajar sehingga ketuntasan belajar secara klasikal sebesar 55\% dengan nilai rata-rata hasil belajar siswa adalah 69,65.

Hasil observasi motivasi siswa dan hasil evaluasi siswa pada siklus I menunjukkan bahwa indikator keberhasilan dalam penelitian ini belum terpenuhi. Dari hasil data observasi motivasi belajar siswa, sudah mengalami peningkatan dalam setiap aspek yang diamati. (4) Refleksi

Berdasarkan hasil observasi dan evaluasi selama pelaksanaan siklus I, ada beberapa hal penting yang perlu diperhatikan, diperbaiki dan ditingkatkan karena kegiatan pembelajaran menggunakan model pembelajaran koperatif tipe TPS belum sepenuhnya berjalan sesuai dengan yang diharapkan.

Permasalahan-permasalahan yang terjadi pada siklus I ini perlu didiskusikan dan dicari solusinya agar proses belajar mengajar menggunakan model pembelajaran kooperatif tipe TPS dapat berjalan sebagaimana yang telah direncanakan sebelumnya. Hasil diskusi tersebut di antaranya yaitu guru sebagai pengelola pembelajaran di kelas harus lebih bisa memberikan motivasi agar siswa lebih aktif dalam memecahkan persoalan yang diajukan, baik melalui diskusi kelompok maupun diskusi kelas. Guru harus bisa menciptakan kondisi agar dapat memecahkan permasalahan yang diajukan secara mandiri. Kesempatan siswa untuk mengajukan pendapat lebih diperbanyak lagi agar siswa lebih bisa mengembangkan kemampuannya dalam menjawab persoalan sehingga tidak cenderung bergantung pada arahan gurunya.

Untuk pengelolaan waktu pembelajaran diusahakan seefektif mungkin dan sesuai dengan rencana yang telah dibuat. Karena ketuntasan belajar siswa secara klasikal pada siklus I sebesar 55\% dengan nilai rata-rata siswa adalah 69,65, maka penelitian dilanjutkan ke siklus II dengan materi yang berbeda atau melanjutkan materi yang telah disampaikan pada siklus I.

\section{Pembelajaran Siklus II}

Siklus II dilaksanakan 4 kali pertemuan yaitu tanggal $11 \mathrm{Mei}, 16 \mathrm{Mei}, 18$ Mei, dan 23 Mei 2017. Pada dasarnya proses pembelajaran siklus II sama seperti siklus I. Pada pertemuan pertama disajikan materi tentang pemanfaatan benda-benda di sekitar untuk membuat jaring-jaring bangun ruang sederhana, pertemuan kedua disajikan materi tentang simetri lipat, pertemuan ketiga disajikan materi tentang simetri putar dan pertemuan keempat diadakan evaluasi belajar siklus II.

Di awal pembelajaran bangun ruang siswa masih banyak yang cenderung bersikap menunggu dan pasif untuk melakukan kegiatan belajar, bahkan beberapa siswa masih sibuk sendiri atau bermain-main dengan temannya. Minat dan ketertarikan atau motivasi untuk belajar matematika terlihat rendah sekali, hal ini mengakibatkan siswa kurang siap untuk melakukan kegiatan belajar. Untuk mengatasi masalah kesiapan belajar tersebut di atas, peneliti berupaya membangkitkan motivasi siswa dengan lebih banyak memberi kesempatan kepada siswa untuk melakukan aktivitas belajar bersama guru, sesama siswa dan bahan ajar yang digunakan menggunakan alat peraga.

Setelah mengetahui topik yang akan dicapai, siswa dan guru melakukan dialog dengan beberapa pertanyaan dari guru. Pertanyaan yang diajukan guru yaitu: 1) Pernahkan kalian melihat jaring-jaring kubus? 2) Pernahkan kalian membuat jaring-jaring kubus dengan alat peraga? 3) Pernahkah kalian menggambar jaring-jaring kubus? 4) Bisakah kamu ceritakan bentuk jaring-jaring 
kubus yang kamu ketahui? Mendapat pertanyaan seperti tersebut di atas, hampir semua siswa dapat menjawab pertanyaan 1,2 dan 3 secara lisan sedangkan pertanyaan ke-4 mereka hanya memperlihatkan gambar jaringjaring balok yang ada di buku cetak mereka. Selanjutnya siswa menerima 3 pasang persegi, isolasi, dan gunting. Siswa ditanya oleh guru apakah alat dan bahan tersebut bisa dibuat jaring-jaring balok. Terlihat siswa mengamati dan mengutak-atik alat peraga yang diberikan (tahap think). Tetapi ada juga siswa yang hanya melihat ke arah guru. Kemudian dari kelompok 1 angkat tangan dan mengatakan bahwa alat dan bahan tersebut bisa dibuat jaring-jaring balok. Dari kelompok 3 mengatakan alat dan bahan tersebut tidak bisa dibuat jaring-jaring balok. Sedangkan dari kelompok 5 dan kelompok 2 hanya terdiam dan menatap guru. Kemudian siswa diminta oleh guru membuat jaringjaring balok dengan menggunakan alat dan bahan tersebut (tahap pair). Tetapi terlihat semua kelompok tidak memanfaatkan alat dan bahan yang diberikan untuk membuat jaringjaring kubus. Ada yang membuat rumahrumah, ada yang melempar teman dengan isolasi, ada yang mengunting kertas. Kemudian guru memotivasi siswa membuat kesimpulan tentang membuat jaring- jaring dengan tepat dengan menggunakan alat peraga. Terlihat semua kelompok berdiskusi membuat kesimpulan tentang membuat jaringjaring kubus dengan tepat. Kemudian mempresentasikan hasil kerja kelompok masing-masing (tahap share). Gambar 5.4 menunjukkan jaring-jaring kubus yang didapat siswa menggunakan alat peraga yang diberikan oleh guru.

(1) Rencana Tindakan

Berdasarkan refleksi pada siklus I, maka pada siklus II ini direncanakan kembali tindakan untuk memperbaiki hal-hal yang dianggap masih kurang optimal pada siklus I, diantaranya:

(a) sebaiknya guru lebih sering berkeliling memberikan bimbingan dalam memantau kegiatan siswa dalam pasangannya sekaligus memberikan motivasi belajar kepada siswa sehingga mereka merasa diperhatikan dan tidak ada lagi siswa yang tidak aktif dalam memecahkan permasalahan yang diberikan,

(b) sebaiknya guru memberikan kesempatan bertanya untuk siswa seperlunya saja supaya siswa lebih banyak memikirkan sendiri pemecahan masalah yang diberikan tanpa harus menunggu arahan dari guru,

(c) sebaiknya guru memberikan banyak waktu kepada siswa untuk mengajukan pendapat, sehingga siswa lebih kreatif dan mandiri dalam memecahkan permasalahan,

(d)pengelolaan waktu perlu lebih diperhatikan lagi agar pembelajaran dapat berjalan sesuai dengan rencana.

Selain memperbaiki hal-hal yang dianggap kurang optimal, tindakan yang direncanakan pada siklus II ini adalah sebagai berikut:

(a) membagi siswa menjadi 10 pasang sesuai dengan kelompok terdahulu

(b) menyusun RPP dan LKS siklus II (c) menyusun soal evaluasi siklus II.

(2) Pelaksanaan Tindakan

Pada tahap ini guru kembali melakuka kegiatan pembelajaran menggunakan model pembelajaran kooperatif tipe TPS sesuai dengan rencana yang telah dibuat. Pada siklus II prosedur pelaksanaannya sama seperti siklus I.

(3) Observasi dan Evaluasi 
Berdasarkan hasil penilaian terhadap motivasi siswa pada pertemuan pertama siklus II diperoleh data bahwa semua siswa sudah mulai bisa beradaptasi dengan kelompoknya masing-masing. Mereka mulai bersemangat dalam mendengarkan penjelasan guru dan temannya di depan serta cukup termotivasi dalam memecahkan masalah yang diberikan. Walaupun hanya beberapa kelompok yang lebih dominan dan juga setiap kelompok masih terlihat kaku dalam diskusi kelas.

Berdasarkan

pengamatan, pembelajaran yang dilakukan oleh guru pada pertemuan kedua, secara keseluruhan semakin meningkat dan berjalan dengan baik. Pasangan-pasangan siswa baik yang ada di belakang maupun di depan sama-sama antusias dalam memecahkan permasalahan yang diberikan guru. Siswa kelihatan kompak dengan pasangannya masing-masing, walaupun kadang sering terjadi perbedaan pendapat di antara mereka.

Berdasarkan hasil pengamatan, pembelajaran yang dilakukan oleh guru pada pertemuan ketiga ini secara keseluruhan berlangsung dengan lancar. Guru telah mampu melaksanakan pembelajaran sesuai dengan rencana yang telah dirancang sebelumnya. Perhatian guru terhadap pasangan siswa terlihat lebih merata dan siswapun lebih aktif baik dalam diskusi kelompok maupun diskusi kelas. Guru telah mampu menciptakan suasana yang mendukung sehingga memotivasi siswa agar lebih aktif dalam proses pembelajaran dan membiarkan siswa bekerja mandiri tanpa selalu tergantung arahan guru dalam memecahkan permasalahan yang diberikan. Setiap pasangan siswapun menunjukkan persaingan yang sehat di antara mereka.

Dari hasil evaluasi siswa pada siklus II, diperoleh data sebanyak 19 dari 20 siswa tuntas dalam belajar sehingga ketuntasan belajar secara klasikal sebesar 95\% dengan nilai rata-rata hasil belajar siswa adalah 79,6. Hasil observasi motivasi siswa dan hasil belajar siswa pada siklus II sudah memenuhi indikator keberhasilan dari penelitian yang telah ditetapkan. Motivasi siswa semakin meningkat di setiap pertemuan pada siklus II. Ketuntasan belajar siswa secara klasikal sebesar 95\% atau 19 dari 20 siswa tuntas dalam belajar dengan nilai rata-rata hasil belajar siswa pada siklus II ini adalah 79,6.

Ketuntasan belajar siswa pada siklus II ini sudah memenuhi indikator keberhasilan, maka penelitian dihentikan pada siklus ini dan tidak dilanjutkan ke siklus berikutnya.

\section{Pembahasan}

Hasil pelaksanaan penelitian pada siklus I dan II mengalami peningkatan baik dari segi hasil observasi motivasi siswa maupun hasil evaluasi di setiap siklusnya. Pada setiap siklus, pembelajaran dilakukan sebanyak 4 kali pertemuan. Hasil observasi motivasi siswa pada siklus I dan siklus II meningkat di setiap pertemuannya, yaitu pada siklus I sebesar 2,73 dan pada siklus II sebesar 3,13 . Hasil belajar siswa pada siklus I mempunyai rata-rata sebesar 69,65 , sedangkan hasil belajar pada siklus II mempunyai ratarata sebesar 79,6.

\section{Simpulan dan Saran}

\section{Simpulan}

Berdasarkan penelitian yang telah dilakukan, maka dapat ditarik kesimpulan bahwa (1) Model pembelajaran kooperatif tipe TPS dapat meningkatkan motivasi belajar siswa kelas V SDI Pakauman 1 Banjarmasin tahun pelajaran 2017/2018 model pembelajaran kooperatif tipe TPS dapat meningkatkan hasil belajar siswa kelas V SDI Pakauman 1 Banjarmasin tahun pelajaran 2017/2018. 


\section{Saran}

Berdasarkan hasil penelitian dan temuan penelitian, maka disarankan kepada guru untuk menggunakan strategi TPS dalam pembelajaran di sekolah dengan memperhatikan beberapa hal sebagai berikut.

\begin{tabular}{|c|c|}
\hline Aspek & Saran \\
\hline Guru & $\begin{array}{lr}\text { Hendaknya lebih aktif } & \text { ajar } \\
\text { mendesain bahan } & \text { ajan } \\
\text { berupa lembar kerja siswa } \\
\text { dan alat peraga yang } \\
\text { digunakan dalam } \\
\text { pembelajaran, dengan } \\
\text { adanya LKS dan alat } \\
\text { peraga siswa akan terfokus } \\
\text { perhatiannya dan dapat } \\
\text { melakukan TPS secara } \\
\text { kelompok dalam belajar } \\
\text { dengan efektif dan efesien }\end{array}$ \\
\hline Siswa & $\begin{array}{l}\text { Hendaknya terus latihan } \\
\text { membuat jaring-jaring } \\
\text { balok dengan alat peraga } \\
\text { dan latihan menggambar } \\
\text { jaring-jaring balok sebagai } \\
\text { bentuk representasi dalam } \\
\text { belajar materi jaring-jaring } \\
\text { balok }\end{array}$ \\
\hline Proses & $\begin{array}{lr}\text { Hendaknya } & \text { lebih } \\
\text { memberikan } & \text { kesempatan } \\
\text { kepada siswa melakukan } & \\
\text { penemuan dalam belajar } \\
\text { matematika, serta } \\
\text { meningkatkan potensi yang } \\
\text { dimiliki siswa dalam } \\
\text { mengkonstruk sendiri } \\
\text { pengetahuannya }\end{array}$ \\
\hline Sarana & $\begin{array}{lr}\text { Sekolah } & \text { hendaknya } \\
\text { senantiasa melengkapi } \\
\text { saran belajar dan } \\
\text { mencibtakan lingkungan } \\
\text { sekolah sebagai sumber }\end{array}$ \\
\hline
\end{tabular}

\begin{tabular}{|c|c|}
\hline & belajar matematika \\
\hline Pengembangan & $\begin{array}{l}\text { Hendaknya dapat } \\
\text { melakukan penelitian lebih } \\
\text { lanjut tentang potensi siswa } \\
\text { melakukan representasi } \\
\text { dalam belajar matematika, } \\
\text { sehingga peningkatan } \\
\text { kualitas belajar matematika } \\
\text { di sekolah dapat terlaksana } \\
\text { secara berkesinambungan }\end{array}$ \\
\hline Alat peraga & $\begin{array}{l}\text { Hendaknya menyediakan } \\
\text { alat peraga yang jumlahnya } \\
\text { cukup dalam pembelajaran } \\
\text { agar semua siswa dapat } \\
\text { kesempatan menggunakan } \\
\text { alat peraga yang } \\
\text { disediakan. } \\
\text { Alat peraga yang } \\
\text { disediakan hendaknya } \\
\text { disesuaikan dengan materi } \\
\text { dan tujuan pembelajaran }\end{array}$ \\
\hline
\end{tabular}

\section{Daftar Pustaka}

Akbar, S. (2009). Penelitian Tindakan Kelas: Filosofi, metodelogi \& Implementasi. Yogyakarta: Cipta Media Aksara.

Arsyad, A. (2009). Media Pembelajaran. Jakarta: Rajawali Pers.

Azyraf, A. F. (2013). Faktor-Faktor Yang Mempengaruhi Motivasi. Diakses tanggal 9 Juni 2016 dari http://www. wawasanpendidikan.com/2013/07/arti kel-pendidikan-tentang-faktor-faktoryang-mempengaruhi- motivasi.html.

Creswell, J.W. (2012). Research Design Pendekatan Kualitatif, Kuantitatif dan 
Mixed (Edisi Ketiga terjemahan). Yogyakarta : Pustaka Pelajar.

Djamarah, S. B \& Zain, A. (2010). Strategi Belajar Mengajar. Jakarta: Rineka Cipta.

Fathurrohman, P \& Sutikno, M. S. (2011). Strategi Belajar Mengajar. Bandung: Refika Aditama.

Hamalik, O. (2009). Psikologi Belajar dan mengajar. Bandung: PT Sinar Baru Algensind.

Herndon, J.N. (1987). Learner Interest, Achievement and Continuing Motivation on Instruction, Journal of Instructional Development,vol. 10(3), 1114.

Huda, M. (2013). Model-model Pengajaran dan Pembelajaran. Yogyakarta : Pustaka Belajar Offset.

Isjoni. (2011). Cooperative learning. Edisi 5. Bandung: Alfabeta.

Keller, J.M. (1987). Development and Use of ARCS Model of Instructional Design.Journalof Instructional Development, vol 10(3), 2-9.

Latief, M. A. (2010). Tanya jawab Metode Penelitian Pembelajaran Bahasa. Malang: Penerbit Universitas Negeri Malang (UM Press) .

Majid. (2013). Strategi Pembelajaran. Bandung: Remaja Rosdakarya.
Raymon. C, J. (2012). Strategies for reading comprehension : Think Pair Share. Cooperative Learning Community. (Frank Lyman). reading Quest. Org. (Online), Diakses tanggal 9 Juni 2016 dari http://www.readingquest.org/strat/ tps.html.

Slameto. (2010). Belajar dan faktor-faktor yang mempengaruhi. Cetakan ke-5. Jakarta : PT. Rineka Cipta.

Slavin, Robert E. (2005). Cooperatif Learning Teori, Riset dan Praktik. Bandung: Nusa Media.

Soedjadi, R. (2000). Kiat Pendidikan Matematika di Indonesia, Konstitusi Keadaan Masa Kini Menuju Harapan Masa Depan. Jakarta: Direktorat Jendral Pendidikan Tinggi Departemen Pendidikan Nasional.

Sofa. (2008). Motivasi dalam Pembelajaran. Diakses tanggal 9 Juni 2016 dari https://massofa.wordpress.com/2008/01/ 20/motivasi-dalam-pembelajaran/.

Subanji. (2013). Pembelajaran Matematika Kreatif dan Inovatif. Universitas Negeri Malang: UM PRESS. Sujana, Nana. 1990. Teori-Teori Belajar untuk Pengajaran. Jakarta: LPFE UI.

Suprijono, A. (2012). Cooperative Learning Teori dan Aplikasi PAIKEM. Yogyakarta : Pustaka Belajar.

Trianto. (2011). Model-Model Pembelajaran Inovatif Berorientasi Konstruktivistik. Jakarta: Prestasi Pustaka Publisher. 
Uno, H. B. (2011). Teori Motivasi dan Pengukurannya. Jakarta: Bumi Aksara.

Usman, M. Basyiruddin dan Asnawir. (2002). Media Pembelajaran. Jakarta: Ciputra

Zimmerman, B. J., Bonner, S. \& Kovach, R. (1996). Developing Self-Regulated Learners Beyond Achievement to SelfEfficacy (Psychology in The Classroom). USA: American Psychological Association). 